\title{
RENEGOTIATING BOUNDARIES
}


Cover:

Rumanul Hidayat (born in Banjar Negara, Central Java, 1958) is chief of the subdistrict of Cimanggis, in Depok city. It has 400,000 inhabitants, mostly middle-class commuters to Jakarta.

(C) Jan Banning Fotografie, Utrecht, Netherlands (banning@solcon.nl) 
V E R H A N D E L I N G E N

VAN HET KONINKLIJK INSTITUUT

VOOR TAAL-, LAND- EN VOLKENKUNDE

238

\section{RENEGOTIATING BOUNDARIES}

Local politics in post-Suharto Indonesia

Edited by

HENK SCHULTE NORDHOLT and GERRY van KLINKEN

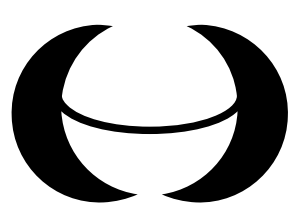

KITLV Press

Leiden

2007 
Published by:

KITLV Press

Koninklijk Instituut voor Taal-, Land- en Volkenkunde

(Royal Netherlands Institute of Southeast Asian and Caribbean Studies)

P.O. Box 9515

2300 RA Leiden

The Netherlands

website: www.kitlv.nl

e-mail: kitlvpress@kitlv.nl

KITLV is an institute of the Royal Netherlands Academy of Arts and Sciences (KNAW)

Cover: Creja ontwerpen, Leiderdorp

ISBN 9789067182834

(C) 2007 Koninklijk Instituut voor Taal-, Land- en Volkenkunde

No part of this publication may be reproduced or transmitted in any form or by any means, electronic or mechanical, including photocopy, recording, or any information storage and retrieval system, without permission from the copyright owner.

Printed in the Netherlands 


\section{Contents}

List of maps vii

Preface $\quad$ ix

Henk Schulte Nordholt and Gerry van Klinken

Introduction 1

Gerry van Klinken

M. Isa Sulaiman (1951-2004) 31

Local society and the dynamics of ethnicity

Lorraine V. Aragon

Elite competition in Central Sulawesi $\quad 39$

Myrna Eindhoven

New colonizers?

Identity, representation and government in the post-New Order Mentawai Archipelago

Jacqueline Vel

$\begin{array}{ll}\text { Campaigning for a new district in West Sumba } & 91\end{array}$

Dik Roth

Many governors, no province;

The struggle for a province in the Luwu-Tana Toraja area in

South Sulawesi

Shadow states and the black economy

John F. McCarthy

Sold down the river;

Renegotiating public power over nature in Central Kalimantan

Erwiza Erman

Deregulation of the tin trade and creation of a local Shadow State;

A Bangka case study

Syarif Hidayat

'Shadow State'?

Business and politics in the province of Banten 203

M. Isa Sulaiman and Gerry van Klinken

The rise and fall of governor Puteh 
Fear and the failure of security

Arianto Sangaji

The security forces and regional violence in Poso

John M. MacDougall

Criminality and the political economy of security in Lombok

How civil is civil society?

David Henley, Maria J.C. Schouten, Alex J. Ulaen

Preserving the peace in post-New Order Minahasa 307

Jim Schiller

Civil society in Jepara; Fractious but inclusive

Taufiq Tanasaldy

Ethnic identity politics in West Kalimantan

Andi Faisal Bakti

Family rule in Wajo, South Sulawesi

Identities under construction

Henk Schulte Nordholt

Bali: An open fortress

Franz and Keebet von Benda-Beckmann

Ambivalent identities;

Decentralization and Minangkabau political communities

Carole Faucher

Contesting boundaries in the Riau Archipelago

Jaap Timmer

Erring decentralization and elite politics in Papua

Glossary

Abbreviations and acronyms

About the authors

Bibliography

Index 


\section{List of maps}

Map 1 The Indonesian Archipelago xii

$\begin{array}{lll}\text { Map } 2 \text { Central Sulawesi (1) } & 44\end{array}$

$\begin{array}{lll}\text { Map } 3 \text { Mentawai Archipelago and West Sumatra } & 68\end{array}$

$\begin{array}{llr}\text { Map } 4 \text { Sumba } & \text { 98-99 }\end{array}$

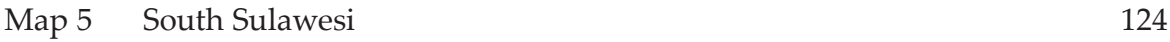

$\begin{array}{lll}\text { Map } 6 \text { Central Kalimantan } & 156\end{array}$

$\begin{array}{lll}\text { Map } 7 & \text { Bangka Belitung } & 178\end{array}$

$\begin{array}{lll}\text { Map } 8 & \text { Banten } & 204\end{array}$

$\begin{array}{lll}\text { Map } 9 & \text { Aceh } & 228\end{array}$

$\begin{array}{lll}\text { Map } 10 \text { Central Sulawesi (2) } & 256\end{array}$

$\begin{array}{lll}\text { Map } 11 & \text { Lombok } & 282\end{array}$

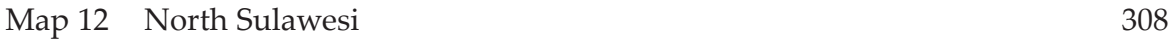

Map 13 Jepara in Central Java 328

$\begin{array}{lll}\text { Map } 14 \text { West Kalimantan } & 350\end{array}$

Map 15 Wajo in South Sulawesi 374

$\begin{array}{lll}\text { Map } 16 & \text { Bali } & 388\end{array}$

$\begin{array}{lll}\text { Map } 17 \text { West Sumatra } & 418\end{array}$

Map 18 Riau Archipelago 444

Map 19 Papua (Irian Jaya) 462 
Henk Schulte Nordholt and Gerry van Klinken - 9789004260436 Downloaded from Brill, com $\odot 4 / 26 / 2023$ 01:22:47PM 


\section{Preface}

For decades almost the only social scientists who visited Indonesia's provinces were anthropologists. Anybody with a special interest in politics or economics spent most of their time in Jakarta, where the action was. The usual pressures facing foreign researchers contributed to this weakness - shrinking budgets and the waning of area studies in the West, a slow research visa process in Indonesia. As a result, academic expertise on the regions beyond Java became fragmented and patchy. Yet as field visits grew shorter, conclusions about the nature of 'Indonesia' became more sweeping in their generality. Our view of the world's fourth largest country threatened to become simplistic, lacking that essential graininess and heterogeneity.

Just then, in 1998, Indonesia was plunged into a crisis that could not be understood with simplistic tools. Massive demonstrations, amidst an economic crisis triggered by a plunging exchange rate, forced President Suharto to resign. After 32 years of enforced stability, the New Order was at an end. Things began to happen in the provinces that no one was prepared for. Democratization was one of them. Everyone wanted it, but there was no doubt that the movement was not equally strong all over the country. The demands were stronger in Java - especially Jakarta - than outside it. The 1999 elections, the freest since 1955, showed strong regional differences. Decentralization was another new development. The push for that was almost the inverse of the democratization drive - stronger outside Java than within. Powers were transferred from Jakarta to the local level, precisely the level to which scholars had paid little attention during the centralizing New Order. The decentralization process set off dynamics for which we hardly had a vocabulary. Ethnic and religious identities emerged that had lain buried under the blanket of the New Order's modernizing, secular ideology. Unfamiliar forms of political competition came to light. Mostly these remained civil, but in a few cases they became violent. New modes of economic exchange came into view. And all this took place in an atmosphere of political and economic crisis.

Today, almost a decade after those tumultuous events of 1998, some of the changes hurriedly introduced back then have turned out to be ephemeral. 
The New Order political party Golkar was back in power in 2004. So was a former general in the presidential palace. Decentralization, too, was being wound back to some extent. Security had improved. But even if the six years between 1998 and 2004 described in this book turn out to be a momentary irruption - and we are convinced they are far more than that - then they still imply profound changes in the way we need to think about the state and society in Indonesia. Our total surprise at the volume of demands for new districts to be carved out of old, and at the emergence of local identity politics - to name just two developments - suggests there was a gap in our understanding. We had made progress at describing Indonesia under conditions of stability, but we had no idea what to expect when stability broke down. To speak about 'chaos', as many did at the time, was no substitute for understanding. Indonesia had far more structure than that word suggests.

This book is the result of a two-year research project, based at the Koninklijk Instituut voor Taal-, Land- en Volkenkunde (KITLV, Royal Netherlands Institute of Southeast Asian and Caribbean Studies), and entitled 'Renegotiating boundaries; Local politics in post-Suharto Indonesia'. It brought together a remarkably international group of 24 scholars - mainly from Indonesia and the Netherlands but also from the United States, Australia, Germany, Canada and Portugal. The KITLV hosted a work-inprogress workshop in July 2004, attended by a number of authors, and invited eight of the authors to spend between a month and six months at the institute for research. ${ }^{1}$ Both editors did their work at the KITLV. Marjan Groen kindly prepared the maps. The Indonesian Institute of Sciences (LIPI) co-hosted the final conference in Jakarta in December 2004, at which the authors discussed each others' work. The entire project was generously funded by the Royal Netherlands Academy of Arts and Sciences (KNAW). To the directors and staff at the KITLV, LIPI, and KNAW, we wish to extend our sincere appreciation for their unstinting support. We hope the results, concretely in this book but also in terms of strengthening academic exchanges, will justify the confidence they placed in us.

Just four days after the Jakarta conference ended, one of our authors lost his life in the tsunami that swept the coasts of Aceh. M. Isa Sulaiman had been an enthusiastic participant in the project throughout its duration. He will be greatly missed. An obituary included in this volume describes his work. We dedicate this book to his memory.

1 They were Lorraine Aragon, Erwiza Erman, Syarif Hidayat, John MacCarthy, Isa Sulaiman, Arianto Sangaji, Andi Faisal Bakti and Carole Faucher. 
Henk Schulte Nordholt and Gerry van Klinken - 9789004260436 Downloaded from Brill, com $\odot 4 / 26 / 2023$ 01:22:47PM 


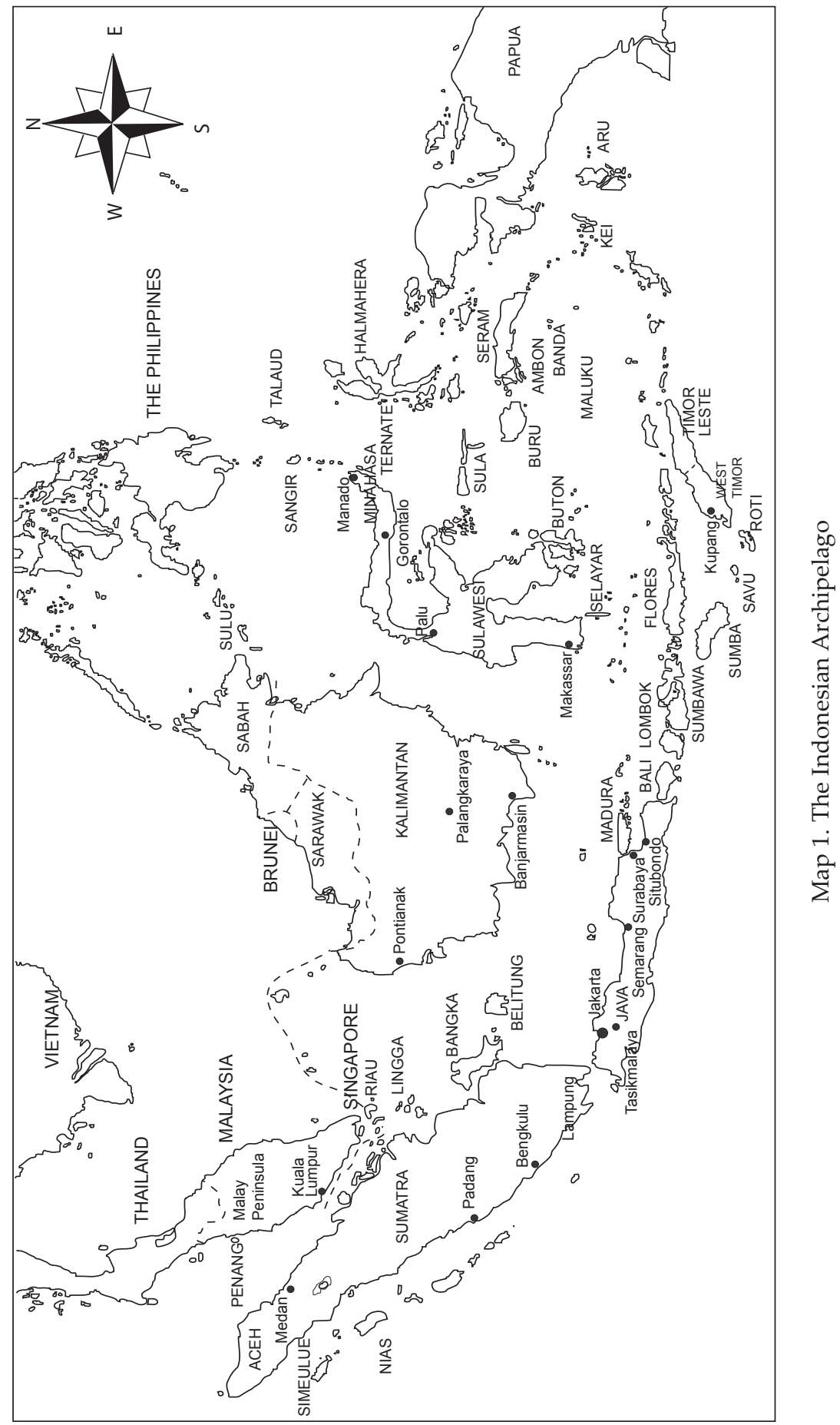

